\title{
Effect of Temperature on Wheat Streak Mosaic Disease Development in Winter Wheat
}

E. N. Wosula, International Institute of Tropical Agriculture, Dar es Salaam, Tanzania; S. Tatineni, United States Department of AgricultureAgricultural Research Service, and Department of Plant Pathology, University of Nebraska-Lincoln, Lincoln 68583; S. N. Wegulo, Department of Plant Pathology, University of Nebraska-Lincoln; and G. L. Hein, Department of Entomology, University of Nebraska-Lincoln

\begin{abstract}
Temperature is one of the key factors that influence viral disease development in plants. In this study, temperature effect on Wheat streak mosaic virus (WSMV) replication and in planta movement was determined using a green fluorescent protein (GFP)-tagged virus in two winter wheat cultivars. Virus-inoculated plants were first incubated at $10,15,20$, and $25^{\circ} \mathrm{C}$ for 21 days, followed by $27^{\circ} \mathrm{C}$ for 14 days; and, in a second experiment, virus-inoculated plants were initially incubated at $27^{\circ} \mathrm{C}$ for 3 days, followed by $10,15,20$, and $25^{\circ} \mathrm{C}$ for 21 days. In the first experiment, WSMV-GFP in susceptible 'Tomahawk' wheat at $10^{\circ} \mathrm{C}$ was restricted at the point of inoculation whereas, at $15^{\circ} \mathrm{C}$, the virus moved systemically, accompanied with mild symptoms, and, at 20 and $25^{\circ} \mathrm{C}$, WSMV elicited severe WSMV symptoms. In resistant 'Mace' wheat (PI 651043), WSMV-GFP

was restricted at the point of inoculation at 10 and $15^{\circ} \mathrm{C}$ but, at 20 and $25^{\circ} \mathrm{C}$, the virus infected systemically with no visual symptoms. Some plants that were not systemically infected at low temperatures expressed WSMV-GFP in regrowth shoots when later held at $27^{\circ} \mathrm{C}$. In the second experiment, Tomahawk plants $(100 \%)$ expressed systemic WSMV-GFP after 21 days at all four temperature levels; however, systemic WSMV expression in Mace was delayed at the lower temperatures. These results indicate that temperature played an important role in WSMV replication, movement, and symptom development in resistant and susceptible wheat cultivars. This study also demonstrates that suboptimal temperatures impair WSMV movement but the virus rapidly begins to replicate and spread in planta under optimal temperatures.
\end{abstract}

Wheat streak mosaic virus (WSMV; genus Tritimovirus, family Potyviridae) infects wheat worldwide (Brunt et al. 1996; Dwyer et al. 2007; Ellis et al. 2003; Sánchez-Sánchez et al. 2001; Stenger et al. 1998). It causes 2 to $3 \%$ annual yield loss in wheat in North America (Great Plains) (Appel et al. 2013). In severe epidemics, WSMV usually causes total crop loss in affected fields (Wegulo et al. 2008).

WSMV is transmitted by Aceria tosichella Keifer (wheat curl mite) (Slykhuis 1955; Staples and Allington 1956). The mite also is a vector of two other wheat viruses, Wheat mosaic virus (WMoV), tentatively in the genus Emaravirus (Seifers et al. 1997; Tatineni et al. 2014a) and Triticum mosaic virus (TriMV; genus Poacevirus, family Potyviridae) (Seifers et al. 2009; Tatineni et al. 2009). These viruses are widespread in the Great Plains but WSMV is the most common (Burrows et al. 2008; Byamukama et al. 2013).

Environmental factors are known to influence plant-pathogen interactions, affecting both pathogenicity and host defense responses (Browder 1985; Colhoun 1973). Disease resistance in plants to bacteria, fungi, viruses, and insects is known to vary depending on prevailing temperatures (Garrett et al. 2006). Disease severity can be intense at either low or high temperatures but, in culture, the pathogens may establish under a broad temperature range. This is because the effects of temperature on disease, like those of some other environmental factors, may be due to effects on the host, the pathogen, or an interaction between pathogen and host (Colhoun 1973; Wang et al. 2009).

Temperature-sensitive resistance to plant viruses has been reported in various host-pathogen systems such as cassava and cassava mosaic geminiviruses (Chellappan et al. 2005), tobacco and Tobacco mosaic virus (TMV) (Király et al. 2008), Nicotiana spp. and Tobacco ringspot virus (Siddiqui et al. 2008), and Nicotiana benthamiana and Cymbidium ringspot virus (Szittya et al. 2003). In

Corresponding author: E. N. Wosula; E-mail: e.wosula@cgiar.org

Accepted for publication 26 September 2016.

() 2017 The American Phytopathological Society wheat, temperature-sensitive resistance that impedes WSMV infection and symptom expression has been identified in various germplasm that is either associated with alien chromatin (Wsml gene) (Seifers et al. 1995) or obtained entirely from wheat germplasm (Wsm2) (Fahim et al. 2012; Seifers et al. 2006, 2007). Wsml has been deployed into resistant 'Mace' wheat (PI 651043) (Graybosch et al. 2009), while Wsm2 has been incorporated into 'RonL' and 'Snowmass' (Lu et al. 2011, 2012). Recently, another resistance gene, designated Wsm3, was identified in wheat germplasm, and it prevents WSMV symptom expression at higher temperatures (up to $24^{\circ} \mathrm{C}$ ) (Seifers et al. 2013). Temperature-sensitive resistance in wheat cultivars containing the Wsml or Wsm2 gene is effective at $18^{\circ} \mathrm{C}$ but allows infection and symptom expression when subjected to temperatures ranging between 20 and $28^{\circ} \mathrm{C}$ for sustained periods (Fahim et al. 2012; Seifers et al. 1995, 2006, 2007; Tatineni et al. 2010, 2014b). Recently, Wsm1 and Wsm 2 genes were found to confer resistance in wheat cultivars by temperaturedependent impairment of viral long-distance movement, with no significant effects on virus replication and cell-to-cell movement (Tatineni et al. 2016).

The appearance of visible WSMV symptoms (mosaic or chlorosis) in systemically infected leaves normally indicates virus presence. However, symptomatology does not show the primary site of phloem unloading (Roberts et al. 1997). The introduction of the green fluorescent protein (GFP) gene (Oparka et al. 1996) into viral genomes has permitted the noninvasive monitoring of the progress of viral infections (Baulcombe et al. 1995; Folimonova et al. 2008; Tatineni et al. 2011). In infections by Potato virus $X$, Citrus tristeza virus, and WSMV, GFP expression was used to track virus movement and study the effect of specific gene deletions on cell-to-cell movement (Baulcombe et al. 1995; Cruz et al. 1996; Folimonova et al. 2008; Oparka et al. 1996; Tatineni et al. 2011).

Factors contributing to the impact of WSMV infection on the plant include plant stage at the time of infection and temperature and other environmental stresses during infection (Hunger et al. 1992). In the Great Plains, WSMV damage is usually more severe in cases where winter wheat is planted early in the fall, when temperatures are warmer, or during seasons with warmer growing conditions; however, damage is less severe when wheat is planted late in the fall or during 
seasons with cool fall and spring conditions (McMechan and Hein 2016). It is common for plants that are asymptomatic and negative for WSMV via enzyme-linked immunosorbent assay (ELISA) during fall and early spring to develop severe symptoms soon after temperatures increase in spring. Knowledge of the interaction between viral disease development and temperature is important in predicting plant response to infection and developing recommendations for effective management. The main objective was to study the effect of different temperature regimes on the replication, movement, and symptom expression of WSMV using a GFP-tagged virus in virus-resistant (Mace) and virus-susceptible ('Tomahawk') winter wheat cultivars.

\section{Materials and Methods}

Virus inoculum. A GFP-tagged WSMV (Sidney 81 strain) expression vector, designated as pSP6-WSMV-GFP-NIb/CP(11aa), was used in this study (Tatineni et al. 2011). This construct (hereafter designated as WSMV-GFP) stably expressed GFP in wheat and elicited symptoms in wheat (chlorotic streaks or spots, mosaic, and mottling) similar to those of wild-type WSMV Sidney 81, except for a delay of 1 to 2 days (Tatineni et al. 2011). Wheat leaves infected with in vitro transcript of pSP6-WSMV-GFP-NIb/CP(11aa) were used for inoculum preparation.

Wheat plants. Two winter wheat cultivars (Mace and Tomahawk) were used in this study. Mace (PI 651043), developed by the United States Department of Agriculture-Agricultural Research Service and the Nebraska Agricultural Experiment Station, is a hard red winter wheat cultivar adapted to rainfed and irrigation production (Graybosch et al. 2009). Resistance to WSMV in Mace is conditioned by the Wsml gene, which was sourced from intermediate wheatgrass Thinopyrum intermedium (Host) Barkworth \& D. R. Dewey (Friebe et al. 1991; Seifers et al. 1995). Tomahawk (Agripro BioSciences) is highly susceptible to WSMV and currently under limited field production in the Great Plains region but it is often used as a WSMV-susceptible check (Divis et al. 2006; Seifers et al. 2007).

Experiment I. Four temperature regimes were selected to evaluate their effect on virus movement and replication in wheat plants (10, 15,20 , and $25^{\circ} \mathrm{C}$ ). The experimental design was a Latin square with four temperature levels and four replications, with 10 plants within each replicate for each temperature-cultivar combination. Each replicate comprised the four temperature treatments randomly allocated to four growth chambers (Percival Scientific, Inc.), such that each growth chamber was used once for each temperature treatment. This was done to account for the variability in photosynthetic photon flux density in the chambers (range 130 to $320 \mu \mathrm{mol} / \mathrm{m}^{2} \mathrm{~s}$ ). Within the main plot temperature treatments, split-plot treatments of the two cultivars were included. The growth chambers were held at 30 to $40 \%$ relative humidity and a photoperiod of $14 \mathrm{~h}$ of light and $10 \mathrm{~h}$ of darkness. Wheat seedlings were established individually in 4-cm-diameter Cone-tainers (Stuewe \& Sons, Inc.) and maintained under standard greenhouse conditions, as described by Wosula et al. (2016). After 10 days, wheat plants were moved to the laboratory and mechanically inoculated with WSMV-GFP. A 5-cm section of the second leaf of each plant was inoculated by rubbing the inoculum (infected leaf tissue ground in sterile water, 1:10 [wt/vol]) onto leaves using individual cotton buds. The leaf tips were rinsed using distilled water shortly after inoculation.

After virus inoculation, plants were placed at the appropriate treatment temperature and observed at 3, 7, 14, and 21 days postinoculation (dpi) for GFP expression. GFP presence in different leaves was observed and the number of infection foci at the inoculated 5-cm leaf section was counted with the aid of a Zeiss Stereo Discovery V12 Fluorescence Microscope by using a GFP narrow-band filter set at 38 (excitation 400 to $450 \mathrm{~nm}$ and emission 450 to $490 \mathrm{~nm}$; Carl Zeiss Micro Imaging, Inc.).

After $21 \mathrm{dpi}$, the top two fully expanded leaves of five plants per treatment were harvested and WSMV titer was quantified by using quantitative reverse-transcription polymerase chain reaction (QRT-PCR) (replicate 1 and 2) or tested for presence of WSMV by using doubleantibody sandwich (DAS)-ELISA (replicate 3 and 4). After harvesting leaves, these plants (five per treatment) were cut back to approximately $2 \mathrm{~cm}$ above soil level and then held at $27^{\circ} \mathrm{C}$ to allow regrowth. The regrowth was observed for expression of WSMV-GFP after 21 days.
The five unharvested plants from each temperature-cultivar-replicate combination were moved to a growth chamber, held at $27^{\circ} \mathrm{C}$, and observed at 3, 7, and 14 days for GFP expression. After 14 days, the top two fully expanded leaves were harvested and WSMV virus titer was quantified by using QRT-PCR (replicate 1 and 2) or tested for presence of WSMV by using DAS-ELISA (replicate 3 and 4). Data were recorded on number of days required to express GFP by WSMVGFP at the point of inoculation, number of infection foci (localized virus centers at the point of initial infection) at the point of inoculation, and percentage of plants expressing WSMV-GFP at the point of inoculation, systemically and in regrowth. This experiment was conducted four times.

Experiment II. A second experiment was conducted with 10-day old wheat plants that were inoculated with WSMV-GFP as described above and immediately held at $27^{\circ} \mathrm{C}$ for three days to allow virus replication and cell-to-cell movement at the point of inoculation, but limiting systemic infection. Plants were then placed at either 10, 15, 20 , or $25^{\circ} \mathrm{C}$ for 21 days. At 21 days, the top two fully-expanded leaves were harvested, and plants were cut back to approximately $2 \mathrm{~cm}$ and held at $27^{\circ} \mathrm{C}$ for 14 days to allow for regrowth. The harvested leaves were tested for WSMV-GFP by DAS-ELISA. Data were recorded as in experiment I, and the experiment was conducted twice.

DAS-ELISA assays on test plants. Samples were tested for WSMV in duplicate using DAS-ELISA, following procedures previously described by Wosula et al. (2016). Sample extracts were prepared by grinding leaf tissue in general extraction buffer at a 1:10 (wt/vol) ratio (Agdia, Inc.). Samples were loaded (100 $\mu 1 /$ well) in 96-well ELISA plates (Thermo Scientific, Inc.) coated with WSMV capture antibody (Agdia, Inc.) and incubated at $37^{\circ} \mathrm{C}$ for $1 \mathrm{~h}$. The plates were rinsed and WSMV conjugate antibody (Agdia, Inc.) was added and incubated at $37^{\circ} \mathrm{C}$ for $1 \mathrm{~h}$. After rinsing the plates, p-nitrophenyl phosphate $(100 \mu \mathrm{l})$ was added and plates were held in the dark for $1 \mathrm{~h}$. Absorbance $(405 \mathrm{~nm})$ was determined using a Multiscan FC Spectrophotometer (Thermo Fisher Scientific, Inc.). Samples with absorbance values at least three times the negative control (healthy tissue) were considered positive.

QRT-PCR assays. WSMV was quantified using QRT-PCR according to the procedures described by Tatineni et al. (2010). Leaf tissue (approximately $200 \mathrm{mg}$ ) harvested from the upper leaves was ground in liquid nitrogen and mixed with TriPure reagent (Roche). The mixture was transferred to an Eppendorf tube, chloroform was added, and the contents were mixed thoroughly, followed by incubation for $10 \mathrm{~min}$ at room temperature and vortexing at $12,000 \times \mathrm{g}$ for $15 \mathrm{~min}$. The supernatant $(200 \mu \mathrm{l})$ was transferred to new tubes and total RNA was precipitated using isopropanol. The pellet was rinsed with $70 \%$ ethanol, air dried, and dissolved in $125 \mu$ l of sterile water. The integrity of RNA was determined using a spectrophotometer (NanoDrop Lite; Thermo Scientific, Inc.) and cDNA was synthesized using $1 \mu \mathrm{g}$ of RNA.

QRT-PCR was carried out using the Applied Biosystems 7300 Real-Time PCR System. The thermal cycling conditions were $50^{\circ} \mathrm{C}$ for $2 \mathrm{~min}, 95^{\circ} \mathrm{C}$ for $15 \mathrm{~min}$, and 40 cycles at $95^{\circ} \mathrm{C}$ for $15 \mathrm{~s}$ and $58^{\circ} \mathrm{C}$ for $60 \mathrm{~s}$. Reactions were conducted in duplicate using primers and probes specific to WSMV and 18S ribosomal RNA (internal control) (Tatineni et al. 2010). The absolute number of genomic RNA copies of WSMV was calculated from the threshold cycle values of real-time RT-PCR by using Q-Gene software (Muller et al. 2002; Pfaffl et al. 2002).

Data analysis. Data analysis was carried out using SAS software (version 9.4; SAS Institute, Inc.). The number of days to expression of WSMV-GFP foci and the number of foci were tested for differences using PROC GLIMMIX with a Poisson distribution. The percentage of plants expressing WSMV-GFP at the point of inoculation showing systemic infection and the number of RNA molecules were $\log$ transformed and tested for differences by using PROC GLIMMIX; however, nontransformed data are reported. The LSMEANS statement was used to obtain least squares means and the TukeyKramer test at $P=0.05$ was used for pairwise comparison of treatment means. Fixed factors were temperature and wheat cultivar, and replicate was included as a random factor. Means and standard errors for the number of days to WSMV-GFP expression at the point 
of inoculation, numbers of foci at the point of inoculation, and the number of RNA molecules were obtained by using the PROC MEANS statement. ELISA results were reported as percent infection without analysis, because they were used to confirm infection by WSMV in the presence of WSMV-GFP expression and to determine the sensitivity of ELISA to detect WSMV in plants expressing WSMV-GFP.

\section{Results}

Experiment I. The expression of visual virus symptoms in wheat plants inoculated with WSMV-GFP was influenced by temperatures and cultivar. Tomahawk plants held at $10^{\circ} \mathrm{C}$ did not develop symptoms after $21 \mathrm{dpi}$ but, at $15^{\circ} \mathrm{C}$, they developed occasional mild mottling. Tomahawk plants held at 20 and $25^{\circ} \mathrm{C}$ developed typical WSMV symptoms (chlorotic streaks or spots, mosaic, and mottling). Mace plants held at all four temperatures did not show WSMV symptoms after $21 \mathrm{dpi}$, although 30 and $65 \%$ of those at 20 and $25^{\circ} \mathrm{C}$, respectively, expressed GFP systemically after 21 dpi (Table 1).

Temperature and cultivar had significant effects on the percentage of plants that elicited infection at the point of inoculation at 3 dpi (temperature: $F=8.5$; df $=3,9 ; P=0.005$, cultivar: $F=5.3$; $\mathrm{df}=1$, $12 ; P=0.039$ ), 7 dpi (temperature: $F=12.0 ; \mathrm{df}=3,9 ; P=0.029$, cultivar: $F=6.8 ; \mathrm{df}=1,12 ; P=0.023$ ), and $14 \mathrm{dpi}$ (temperature: $F=24.0$; $\mathrm{df}=3,9 ; P=0.0001$, cultivar: $F=6.2 ; \mathrm{df}=1,12 ; P=0.007)($ Table 1$)$. However, at $21 \mathrm{dpi}$, temperature differences were not significant $(F=$ $2.7 ; \mathrm{df}=3,9 ; P=0.109)$ and cultivar differences only approached significance $(F=4.4 ; \mathrm{df}=1,12 ; P=0.060)$. No significant interactions occurred between temperature and cultivar at 3, 7, 14, and 21 days (Table 1). Mace plants held at 10 and $15^{\circ} \mathrm{C}$ did not express GFP at 3 dpi at the point of inoculation but GFP was observed in $38 \%$ of plants held at 20 and $25^{\circ} \mathrm{C}$. At $21 \mathrm{dpi}$, no differences were observed in expression at the point of inoculation at the four temperatures in Mace (57 to 92\%). In Tomahawk, at $21 \mathrm{dpi}$, no differences were observed in the expression of GFP at the point of inoculation at the four temperatures (77 to 100\%).

No systemic movement of virus was detected in either cultivar after 3 days at any temperature examined. Only temperature had significant effects on the percentage of plants infected systemically at 7 days (temperature: $F=5.9$; df $=3,9 ; P=0.017$ ). At $7 \mathrm{dpi}$, no Tomahawk plants had systemic infection (GFP expression in noninoculated leaves) at 10 and $15^{\circ} \mathrm{C}$, while 20 and $60 \%$ of the plants were infected at 20 and $25^{\circ} \mathrm{C}$, respectively. In Mace at $7 \mathrm{dpi}$, no systemic infection was observed in plants held at 10 and $15^{\circ} \mathrm{C}$, while those at 20 and $25^{\circ} \mathrm{C}$ had 5 and $20 \%$ of the plant with systemic infection, respectively. Both temperature and cultivar had significant effects at 14 dpi (temperature: $F=32.8$; df $=3,9 ; P<0.0001$, cultivar: $F=9.7$; $\mathrm{df}=1,12 ; P=0.009)$ and $21 \mathrm{dpi}$ (temperature: $F=30.2 ; \mathrm{df}=3,9$; $P<0.0001$, cultivar: $F=24.7$;f $=1,12 ; P=0.0003$ ). Significant interactions were observed between temperature and cultivar at $21 \mathrm{dpi}$ $(F=6.8 ; \mathrm{df}=3,12 ; P=0.006)$ but no interactions occurred at 3,7 , and $14 \mathrm{dpi}$ (Table 1). The interaction at $21 \mathrm{dpi}$ resulted from a more rapid increase in systemic infection at 15 and $20^{\circ} \mathrm{C}$, with 33 and $100 \%$ infection in Tomahawk compared with only 2.5 and $30 \%$ in Mace plants, respectively; however, expression rates were both zero at $10^{\circ} \mathrm{C}$ and comparable at $25^{\circ} \mathrm{C}$ (Table 1). The percentage of plants expressing WSMVGFP at either the point of inoculation or systemically was generally lower in Mace compared with Tomahawk across all temperatures.

Over $50 \%$ of plants expressed GFP at the point of inoculation by $21 \mathrm{dpi}$ in both Mace and Tomahawk held at $10^{\circ} \mathrm{C}$ but none of these plants was infected systemically (Table 1). GFP was expressed as individual foci in upper noninoculated Mace leaves but not in all leaves and, sometimes, only a few foci were seen in the entire plant. In Tomahawk, GFP was localized at low temperatures but was intense and uniformly distributed in leaves at higher temperatures $\left(20\right.$ and $\left.25^{\circ} \mathrm{C}\right)$.

Days to development of foci at the point of inoculation decreased significantly with increasing temperature up to $21 \mathrm{dpi}$ : 17.0, 9.8, 5.4, and 4.2 days at $10,15,20$, and $25^{\circ} \mathrm{C}$, respectively $(F=82.5 ; \mathrm{df}=3$, $115 ; P<0.0001)$. Smaller but significant differences were also seen between Tomahawk ( 8.5 days) and Mace (9.8 days) $(F=10.1 ; \mathrm{df}=1$, $115 ; P=0.005)$. No significant interaction between temperature and cultivar was seen $(F=0.03 ; \mathrm{df}=3,115 ; P=0.983)$. This indicates that foci initiation occurred sooner for Tomahawk but the increase in the days to development of foci with decreasing temperature was similar between cultivars. The number of foci at the point of inoculation in plants held at the four temperature regimes (3.9 foci; range 3.6 to 4.5$)$ did not differ significantly after 21 dpi $(F=0.9$; $\mathrm{df}=3,115 ; P=0.494)$. However, there were significantly fewer foci in Mace (2.8 foci) compared with Tomahawk (5.0 foci) $(F=60.2$; $\mathrm{df}=1,115 ; P<0.0001)$. There was no significant interaction between temperature and cultivar $(F=0.6 ; \mathrm{df}=3,115 ; P=0.599)$.

WSMV was not detected using QRT-PCR at 21 dpi in Tomahawk plants held at $10^{\circ} \mathrm{C}$ whereas, at $15^{\circ} \mathrm{C}$, it was detected and titer was lower compared with plants held at 20 and $25^{\circ} \mathrm{C}$ (Table 2). In Mace, WSMV was not detected in plants that were held at 10,15 , and $20^{\circ} \mathrm{C}$ but was detected only in those that were held at $25^{\circ} \mathrm{C}$. Accumulation of WSMV genomic RNA in wheat plants incubated at 10, 15, 20, and $25^{\circ} \mathrm{C}$ as measured with QRT-PCR at $21 \mathrm{dpi}$ was significantly affected by temperature $(F=27.6 ; \mathrm{df}=3,3 ; P=0.011)$ and cultivar $(F=31.6 ; \mathrm{df}=1,4 ; P=0.005)$. There was a significant interaction between cultivar and temperature $(F=9.6$; $\mathrm{df}=3,4 ; P=0.027)$, which resulted from the more rapid increase in titer across the lower temperatures for Tomahawk and the lack of difference in WSMV titer in Tomahawk and Mace at $25^{\circ} \mathrm{C}$ (Table 2). In replicates 3 and 4 , in which ELISA was used to test for presence of WSMV, no virus was detected in Tomahawk and Mace plants that were held at $10^{\circ} \mathrm{C}$ which also did not express systemic GFP. WSMV was detected in $20 \%\left(15^{\circ} \mathrm{C}\right)$ and $100 \%\left(20\right.$ and $\left.25^{\circ} \mathrm{C}\right)$ of the Tomahawk plants that expressed systemic GFP. In Mace, WSMV was detected in 6 of the 10 plants that expressed systemic GFP at 15,20 , and $25^{\circ} \mathrm{C}$ (Table 3 ).

Table 1. Percentage of wheat plants expressing local or systemic green fluorescent protein (GFP)-tagged Wheat streak mosaic virus infection at four temperature (temp) levels at 3, 7, 14, and 21 days postinoculation (dpi) ${ }^{\mathrm{x}}$

\begin{tabular}{|c|c|c|c|c|c|c|c|c|}
\hline \multirow[b]{2}{*}{ Cultivar, temp $\left({ }^{\circ} \mathrm{C}\right)$} & \multicolumn{2}{|c|}{3 dpi } & \multicolumn{2}{|c|}{7 dpi } & \multicolumn{2}{|c|}{14 dpi } & \multicolumn{2}{|c|}{21 dpi } \\
\hline & GFP-PI ${ }^{y}$ & GFP-Sys $^{z}$ & GFP-PI & GFP-Sys & GFP-PI & GFP-Sys & GFP-PI & GFP-Sys \\
\hline \multicolumn{9}{|l|}{ Tomahawk } \\
\hline 10 & $0 \mathrm{~b}(0)$ & $0(0)$ & $0 \mathrm{~b}(0)$ & $0 \mathrm{~b}(0)$ & $50 \mathrm{ab}(10)$ & $0 \mathrm{c}(0)$ & 77.5 a (31) & $0 \mathrm{c}$ \\
\hline 15 & $0 \mathrm{~b}(0)$ & $0(0)$ & $50 \mathrm{ab}(10)$ & $0 \mathrm{~b}(0)$ & 95 a (19) & 5 bc(1) & 90 a (36) & $33 \mathrm{ab}(13)$ \\
\hline 20 & 55 a (11) & $0(0)$ & 100 a (20) & $20 \mathrm{ab}(4)$ & 100 a (20) & 100 a (20) & 100 a (40) & 100 a (40) \\
\hline 25 & 65 a (13) & $0(0)$ & 90 a (18) & 60 a (12) & 90 a (18) & $70 \mathrm{ab}(14)$ & 85 a (34) & 85 a (34) \\
\hline \multicolumn{9}{|l|}{ Mace } \\
\hline 10 & $0 \mathrm{~b}(0)$ & $0(0)$ & $0 \mathrm{~b}(0)$ & $0 \mathrm{~b}(0)$ & $0 \mathrm{~b}(0 / 20)$ & $0 \mathrm{c}(0)$ & 57.5 a (23) & $0 \mathrm{c}(0)$ \\
\hline 15 & $0 \mathrm{~b}(0)$ & $0(0)$ & $35 \mathrm{ab}(7)$ & $0 \mathrm{~b}(0)$ & 65 a (13) & $0 \mathrm{c}(0)$ & 72.5 a (29) & $2.5 \mathrm{c}(1)$ \\
\hline 20 & $25 \mathrm{ab}(5)$ & $0(0)$ & 75 a (15) & $5 \mathrm{ab}(1)$ & 85 a (17) & $15 \mathrm{bc}(3)$ & 80 a (32) & $30 \mathrm{bc}(12)$ \\
\hline 25 & $50 \mathrm{ab}(10)$ & $0(0)$ & 70 a (14) & $20 \mathrm{ab}(4)$ & 75 a (15) & $45 \mathrm{ab}(9)$ & 92.5 a (37) & 65 a (26) \\
\hline
\end{tabular}

${ }^{\mathrm{x}}$ Numbers in parenthesis represent the number of infected plants out of 20 (3, 7, and $\left.14 \mathrm{dpi}\right)$ or 40 (21 dpi). Means with the same letter within columns are not significantly different (Tukey-Kramer, $P<0.05$ ).

${ }^{y}$ GFP-PI = GFP present at point of inoculation (5-cm upper portion of the second leaf).

${ }^{\mathrm{z}}$ GFP-Sys $=$ GFP present in leaves above the second inoculated leaf (third, fourth, or fifth). 
After 21 dpi, half of the test plants were moved to a constant temperature of $27^{\circ} \mathrm{C}$ for 14 days. Tomahawk plants previously held at 10 and $15^{\circ} \mathrm{C}$ expressed noticeable symptoms within 7 days after moving them to $27^{\circ} \mathrm{C}$, while those previously held at 20 and $25^{\circ} \mathrm{C}$ rapidly developed severe WSMV symptoms at $27^{\circ} \mathrm{C}$. When Mace plants held at $25^{\circ} \mathrm{C}$ were moved to $27^{\circ} \mathrm{C}$ for 14 days, $34 \%$ of them displayed localized mild chlorotic mottling, while the rest remained symptomless. No significant differences were seen in systemic infection between temperatures or cultivars (temperature: $F=0.8 ; \mathrm{df}=3,9 ; P=0.524$, cultivar: $F=4.3 ; \mathrm{df}=1$, $12 ; P=0.062)$. However, the cultivar effect was marginal, resulting from more Tomahawk plants (range 90 to $100 \%$ ) than Mace plants (range 50 to 85\%) expressing systemic GFP. No significant interaction occurred between temperature and cultivar $(F=0.68$; df $=3,12 ; P=$ 0.579 ) because the differences seen at 21 dpi were no longer observed.

After holding plants for 21 days at the four temperature regimes and then at $27^{\circ} \mathrm{C}$ for 14 days, virus titer was no longer affected by temperature $(F=0.17$; df $=3,3 ; P=0.913)$ or cultivar $(F=7.8$; $\mathrm{df}=1,4 ; P=0.068$ ) (Table 2). Using QRT-PCR, WSMV was detected in all Tomahawk plants (38 of 38) that had systemic infection and in 19 of the 21 Mace plants that had systemic infection. In replicates 3 and 4 in which ELISA was used to confirm WSMV in plants expressing GFP, the virus was detected in all Tomahawk plants and in 32 of 36 Mace plants that expressed GFP systemically (Table 3).

In plants allowed to regrow at $27^{\circ} \mathrm{C}$ for 14 days, all Tomahawk plants expressing systemic WSMV-GFP in plants previously incubated at 20 and $25^{\circ} \mathrm{C}$ ( $\left.21 \mathrm{dpi}\right)$ had the virus in regrowth shoots. In Tomahawk, 29 of $33(88 \%)$ of plants that failed to express systemic WSMV-GFP infection at 10 and $15^{\circ} \mathrm{C}$ expressed virus in regrowth shoots (Table 4). In Mace, only 16 of $39(41 \%)$ of plants that failed to express systemic WSMV-GFP infection at 10 and $15^{\circ} \mathrm{C}$ expressed virus in regrowth shoots (Table 4).

Experiment II. Symptom expression in plants was similar to what was observed in experiment I. Tomahawk plants held at $10^{\circ} \mathrm{C}$ did not develop symptoms after $21 \mathrm{dpi}$ but, at $15^{\circ} \mathrm{C}$, they developed occasional mild mottling. Tomahawk plants held at 20 and $25^{\circ} \mathrm{C}$ developed typical WSMV symptoms. Mace plants held at all four temperatures did not show WSMV symptoms after $21 \mathrm{dpi}$. By $3 \mathrm{dpi}$ at $27^{\circ} \mathrm{C}$, nearly all plants expressed GFP at the point of inoculation in Tomahawk (40 of 40) and Mace (39 of 40); however, none of the plants had systemic expression of GFP. At 3 days after transferring plants to the four temperatures, Tomahawk plants expressed systemic GFP in 100,50 , and $0 \%$ of the plants held at 20 and 25,15 , and $10^{\circ} \mathrm{C}$, respectively. In Mace, no plants expressed systemic GFP at 3 days after transference to the four temperatures. There were significant temperature and cultivar effects on the percentage of plants expressing systemic GFP after transference to $10,15,20$, and $25^{\circ} \mathrm{C}$ for 3 days (temperature: $F=91.7 ; \mathrm{df}=3,3 ; P=0.002$; cultivar: $F=625.0 .0$; df $=1,4 ; P<0.0001$; interaction between temperature and cultivar $F=91.7 ; \mathrm{df}=3,4 ; P=0.0004)$. This significant interaction between cultivar and temperature resulted from the rapid infection in Tomahawk ( 0 to $100 \%$ ) compared with Mace $(0 \%)$ across the four temperature levels. At 7 days, only cultivar was significant $(F=44.3$; $\mathrm{df}=1,4$; $P=0.002)$ and, at 14 days, both temperature and cultivar were significant (temperature: $F=9.6$; df $=3,3 ; P=0.048$; cultivar: $F=56.8$; $\mathrm{df}=1,4 ; P=0.002)$. No significant interactions occurred between temperature and cultivar at 7 days $(F=1.5 ; \mathrm{df}=3,4 ; P=0.342)$ and 14 days $(F=5.2 ; \mathrm{df}=3,4 ; P=0.073)$ (Table 5). At 21 days, temperature, $(F=44.6 ; \mathrm{df}=3,3 ; P=0.006)$, cultivar $(F=226.5$; df $=1,4 ; P=0.0001)$, and their interaction $(F=44.6$; df $=3,4$; $P=0.002)$ were all significant. This interaction resulted from $100 \%$ of Tomahawk plants systemically expressing virus across all temperatures, whereas systemic virus expression in the Mace plants increased from $10 \%$ at $10^{\circ} \mathrm{C}$ to $100 \%$ at $25^{\circ} \mathrm{C}$.

The number of foci in plants held at $27^{\circ} \mathrm{C}$ for 3 days was significantly smaller in Mace compared with Tomahawk $(F=44.7 ; \mathrm{df}=1$, $76 ; P<0.0001)$. The mean number of foci across all temperatures was $5.2( \pm 0.46)$ in Mace and $14.5( \pm 1.51)$ in Tomahawk. WSMV was detected by ELISA in 100\% (60 of 60) of the Tomahawk plants held at 15,20 , and $25^{\circ} \mathrm{C}$ but only $25 \%$ ( 5 of 20 ) of those held at $10^{\circ} \mathrm{C}$. In Mace, WSMV was detected in 60\% (12 of 20) of the plants held at $25^{\circ} \mathrm{C}$ but only $5 \%$ (3 of 60 ) of plants held at 10,15 , and $20^{\circ} \mathrm{C}$ that expressed systemic WSMV-GFP infection after 21 days at the four temperature levels (Table 5).

All Tomahawk plants and $85 \%$ of Mace plants incubated at all four temperature regimens expressed WSMV-GFP systemic infection in regrowth shoots after 21 days at $27^{\circ} \mathrm{C}$. Mace plants held at 10,15 , and $20^{\circ} \mathrm{C}$ for 21 days had variable expression of WSMV-GFP systemic infection, ranging from 10 to $65 \%$, but plants showed a higher level of virus in regrowth shoots, ranging from 75 to $90 \%$ (Table 4).

\section{Discussion}

This study revealed that temperature dramatically affects WSMV replication, movement, titer, and symptom expression in a susceptible

Table 3. Percentage of plants that tested positive to green fluorescent proteintagged Wheat streak mosaic virus (WSMV-GFP) using enzyme-linked immunosorbent assay (ELISA) in Mace and Tomahawk plants held at 10, 15, 20, and $25^{\circ} \mathrm{C}$ at 21 days postinoculation (dpi) followed by at $27^{\circ} \mathrm{C}$ for 14 days ${ }^{2}$

\begin{tabular}{lccc}
\hline Cultivar & Temperature $\left({ }^{\circ} \mathbf{C}\right)$ & $\mathbf{2 1} \mathbf{~ d p i}$ & $\mathbf{1 4}$ days at $\mathbf{2 7}^{\circ} \mathbf{C}$ \\
\hline Tomahawk & 10 & $0(0 / 0)$ & $100(10 / 10)$ \\
& 15 & $20(2 / 2)$ & $100(10 / 10)$ \\
& 20 & $100(10 / 10)$ & $100(10 / 10)$ \\
Mace & 25 & $100(10 / 10)$ & $100(10 / 10)$ \\
& 10 & $0(0 / 0)$ & $90(9 / 10)$ \\
& 15 & $10(1 / 1)$ & $80(8 / 9)$ \\
& 20 & $10(1 / 1)$ & $60(6 / 8)$ \\
& 25 & $40(4 / 8)$ & $90(9 / 9)$ \\
\hline
\end{tabular}

${ }^{\mathrm{z}}$ Numbers in parentheses represent number of plants out of 10 in which WSMV was detected by ELISA versus those in which it was observed by systemic expression of GFP.

Table 2. Absolute quantification of green fluorescent protein-tagged Wheat streak mosaic virus (WSMV-GFP) in Mace and Tomahawk plants held at 10, 15, 20, and $25^{\circ} \mathrm{C}$ for 21 days and at $27^{\circ} \mathrm{C}$ for 14 days

\begin{tabular}{llr}
\hline & \multicolumn{2}{c}{ Number (means \pm standard error) of WSMV-GFP RNA copies ${ }^{\mathbf{z}}$} \\
\cline { 2 - 3 } Cultivar, temperature $\left({ }^{\circ} \mathbf{C}\right)$ & \multicolumn{1}{c}{$\mathbf{2 1 ~ d p i}$} & \multicolumn{2}{c}{${ }^{\circ} \mathbf{C}$ for $\mathbf{1 4}$ days } \\
\hline Tomahawk & $0 \pm 0 \mathrm{c}(0 / 0)$ & $3.19 \times 10^{5} \pm 2.75 \times 10^{4} \mathrm{a}(10 / 10)$ \\
10 & $3.18 \times 10^{3} \pm 5.99 \times 10^{2} \mathrm{bc}(2 / 2)$ & $5.85 \times 10^{5} \pm 1.52 \times 10^{5} \mathrm{a}(10 / 10)$ \\
15 & $3.71 \times 10^{6} \pm 9.36 \times 10^{5} \mathrm{a}(10 / 10)$ & $3.25 \times 10^{5} \pm 2.73 \times 10^{4} \mathrm{a}(10 / 10)$ \\
20 & $3.54 \times 10^{6} \pm 2.10 \times 10^{6} \mathrm{a}(6 / 6)$ & $3.66 \times 10^{5} \pm 8.77 \times 10^{4} \mathrm{a}(8 / 8)$ \\
25 & & \\
Mace & $0 \pm 0 \mathrm{c}(0 / 0)$ & $4.04 \times 10^{4} \pm 2.02 \times 10^{4} \mathrm{a}(7 / 7)$ \\
10 & $0 \pm 0 \mathrm{c}(0 / 0)$ & $4.69 \times 10^{5} \pm 4.18 \times 10^{5} \mathrm{a}(3 / 2)$ \\
15 & $0 \pm 0 \mathrm{c}(0 / 0)$ & $8.51 \times 10^{4} \pm 2.64 \times 10^{4} \mathrm{a}(6 / 8)$ \\
20 & $6.04 \times 10^{4} \pm 3.16 \times 10^{4} \mathrm{ab}(8 / 8)$ & $3.24 \times 10^{4} \pm 1.91 \times 10^{4} \mathrm{a}(3 / 4)$ \\
25 &
\end{tabular}

${ }^{\mathrm{z}}$ Numbers in parentheses represent number of plants out of $10 \mathrm{in}$ which WSMV-GFP was detected by quantitative reverse-transcription polymerase chain reaction versus those in which it was observed by systemic expression of GFP. Means with the same letter within columns are not significantly different (Tukey-Kramer $P<0.05) ;$ dpi $=$ days postinoculation. 
cultivar (Tomahawk) and these effects were dramatically altered for a virus-resistant wheat cultivar (Mace). The failure of WSMV-GFP to systemically infect Tomahawk at $10^{\circ} \mathrm{C}$ and the production of only mild mottling at $15^{\circ} \mathrm{C}$ indicate that temperatures at $15^{\circ} \mathrm{C}$ and below suppresses WSMV symptoms in susceptible wheat cultivars. Foci at the point of inoculation developed sooner and were more numerous in Tomahawk than in Mace at the four temperature levels. The number of days to foci development decreased with increasing temperatures in both cultivars. These results indicate that low temperatures delay initiation of WSMV infection; however, this relationship differed between the two cultivars.

In resistant Mace, plants held at all four temperatures failed to express WSMV symptoms, and only mild chlorotic mottling developed in $34 \%$ of plants after they were moved to $27^{\circ} \mathrm{C}$ for 14 days. These data confirm that Mace is resistant (lack of symptom expression) to WSMV at $25^{\circ} \mathrm{C}$ and below; however, a majority of plants expressed GFP systemically when they were moved from 10 and $15^{\circ} \mathrm{C}$ for $21 \mathrm{dpi}$ to $27^{\circ} \mathrm{C}$ for 14 days. These data suggest that virus from local foci developed in inoculated leaves at 10 and $15^{\circ} \mathrm{C}$ might have moved systemically when plants were transferred to permissible temperature at $27^{\circ} \mathrm{C}$. These data also suggest that WSMV replication and cell-tocell movement was occurring in inoculated leaves of resistant Mace wheat bearing the Wsml gene. Recently, Tatineni et al. (2016) found that the Wsml gene in Mace provides resistance to WSMV and TriMV by debilitating long-distance movement at $18^{\circ} \mathrm{C}$, with no appreciable effects on virus replication and cell-to-cell movement. These findings are similar to what we observed; however, results from our study indicate that this impairment in WSMV movement also occurs at lower temperatures $\left(10\right.$ and $\left.15^{\circ} \mathrm{C}\right)$ but at different rates in the resistant and susceptible cultivars.

Failure to detect systemic WSMV infection using QRT-PCR in the youngest leaves of Mace plants held at or below $20^{\circ} \mathrm{C}$ at $21 \mathrm{dpi}$ indicates that these temperatures hinder long-distance movement within wheat plants bearing the Wsml gene but virus replication and foci development proceed at the point of inoculation, as observed by Tatineni et al. (2016). However, when these plants were moved to $27^{\circ} \mathrm{C}$ for 14 days, virus titer was similar to that in plants that were previously held at $25^{\circ} \mathrm{C}$. This indicates that temperatures at $20^{\circ} \mathrm{C}$ or below suppress WSMV movement systemically to upper, noninoculated leaves. Tatineni et al. (2016) reported that lower temperatures $\left(18^{\circ} \mathrm{C}\right)$ affected virus long-distance movement in resistant wheat cultivars. Seifers et al. (2013) also observed lack of symptoms at $20^{\circ} \mathrm{C}$ in the Wsm1 resistant check KS86W10-3. In field trials in Nebraska, Mace consistently demonstrated lack of symptoms following mechanical and vector-borne WSMV infections (Graybosch et al. 2009). In terms of systemic virus movement and symptom expression, Mace plants failed to show symptoms at any of the four temperatures, and virus was detected only in plants held at $25^{\circ} \mathrm{C}$. However, Tomahawk remained symptomatic and WSMV was detected at all temperatures, except $10^{\circ} \mathrm{C}$. These results suggest that temperatures at or below $20^{\circ} \mathrm{C}$ are capable of suppressing WSMV symptoms and systemic virus infection in resistant Mace whereas, in susceptible Tomahawk, WSMV symptoms and systemic infection occur at temperatures as low as $15^{\circ} \mathrm{C}$, though symptom expression is slow. These results suggest that, in resistant Mace, symptoms are limited at all temperatures and long-distance movement of WSMV begins to increase when temperatures rise above $15^{\circ} \mathrm{C}$; however, symptoms are expressed as localized foci even at $25^{\circ} \mathrm{C}$.

Prevailing cool temperatures in the fall and spring in the Great Plains region of North America can reduce losses attributed to WSMV even in susceptible cultivars. However, as temperatures increase above $15^{\circ} \mathrm{C}$, severe WSMV symptoms begin to develop in susceptible cultivars, and this likely will result in increased yield

Table 4. Percentage of wheat plants expressing green fluorescent protein (GFP)-tagged Wheat streak mosaic virus systemic infection after being previously held for 21 days postinoculation at $10,15,20$ and $25^{\circ} \mathrm{C}$ (first experiment) or for 3 days at $27^{\circ} \mathrm{C}$ and then at $10,15,20$, and $25^{\circ} \mathrm{C}$ for 21 days (second experiment) and in regrowth shoots after respective plants were cut back and held at $27^{\circ} \mathrm{C}$ for 21 days $^{\mathrm{z}}$

\begin{tabular}{|c|c|c|c|c|c|}
\hline \multirow[b]{2}{*}{ Cultivar } & \multirow[b]{2}{*}{ Temperature $\left({ }^{\circ} \mathrm{C}\right)$} & \multicolumn{2}{|c|}{ First experiment } & \multicolumn{2}{|c|}{ Second experiment } \\
\hline & & GFP-Sys & GFP RG & GFP-Sys & GFP RG \\
\hline \multirow[t]{4}{*}{ Tomahawk } & 10 & $0(0)$ & $85(17)$ & $100(20)$ & $100(20)$ \\
\hline & 15 & $35(7)$ & $95(19)$ & $100(20)$ & $100(20)$ \\
\hline & 20 & $100(20)$ & $100(20)$ & $100(20)$ & $100(20)$ \\
\hline & 25 & $80(16)$ & $80(16)$ & $100(20)$ & $100(20)$ \\
\hline \multirow[t]{4}{*}{ Mace } & 10 & $0(0)$ & $20(4)$ & $10(2)$ & $75(15)$ \\
\hline & 15 & $5(1)$ & $65(13)$ & $20(4)$ & $90(18)$ \\
\hline & 20 & $5(1)$ & $35(7)$ & 65 (13) & $75(15)$ \\
\hline & 25 & $80(16)$ & $85(17)$ & $100(20)$ & $100(20)$ \\
\hline
\end{tabular}

${ }^{\mathrm{z}}$ GFP-Sys $=$ GFP present in the third, fourth, fifth, sixth, or seventh leaves 21 days postinoculation (dpi) and GFP RG $=$ GFP in regrowth at $27^{\circ} \mathrm{C}$ for 21 days.

Numbers in parentheses represent number of plants infected out of a total of 20.

Table 5. Percentage of wheat plants expressing local, systemic green fluorescent protein-tagged Wheat streak mosaic virus (WSMV-GFP) infection previously at a temperature (temp) of $27^{\circ} \mathrm{C}$ for 3 days postinoculation (dpi) and then at $10,15,20$, and $25^{\circ} \mathrm{C}$ for $3,7,14$, and 21 days, and enzyme-linked immunosorbent assay (ELISA) results at 21 days $^{\mathrm{y}}$

\begin{tabular}{|c|c|c|c|c|c|c|c|}
\hline \multirow[b]{2}{*}{ Cultivar, temp $\left({ }^{\circ} \mathrm{C}\right)$} & \multicolumn{2}{|c|}{$3 \mathrm{dpi}$ at $27^{\circ} \mathrm{C}$} & \multicolumn{4}{|c|}{ GFP-Sys $^{z}$} & \multirow{2}{*}{$\frac{\text { ELISA }}{21 \text { days }}$} \\
\hline & GFP-PI & GFP-Sys & 3 days & 7 days & 14 days & 21 days & \\
\hline \multicolumn{8}{|l|}{ Tomahawk } \\
\hline 10 & $100(20)$ & $0(0)$ & 0 c $(0)$ & $40 \mathrm{bc}(8)$ & $70 \mathrm{ab}(14)$ & $100 \mathrm{a}(20)$ & $25(5)$ \\
\hline 15 & $100(20)$ & $0(0)$ & $50 \mathrm{~b}(10)$ & $80 \mathrm{ab}(16)$ & 100 a (20) & $100 \mathrm{a}(20)$ & $100(20)$ \\
\hline 20 & $100(20)$ & $0(0)$ & 100 a (20) & 100 a (20) & 100 a (20) & $100 \mathrm{a}(20)$ & $100(20)$ \\
\hline 25 & $100(20)$ & $0(0)$ & $100 \mathrm{a}(20)$ & 100 a (20) & 100 a (20) & $100 \mathrm{a}(20)$ & $100(20)$ \\
\hline \multicolumn{8}{|l|}{ Mace } \\
\hline 10 & $100(20)$ & $0(0)$ & $0 \mathrm{c}(0)$ & $0 \mathrm{c}(0)$ & $0 \mathrm{c}(0)$ & $10 \mathrm{c}(2)$ & $5(1)$ \\
\hline 15 & 95 (19) & $0(0)$ & $0 \mathrm{c}(0)$ & $0 \mathrm{c}(0)$ & $0 \mathrm{c}(0)$ & $20 \mathrm{c}(4)$ & $5(1)$ \\
\hline 20 & $100(20)$ & $0(0)$ & $0 \mathrm{c}(0)$ & $0 \mathrm{c}(0)$ & 30 bc (6) & $75 \mathrm{~b}(15)$ & $5(1)$ \\
\hline 25 & $100(20)$ & $0(0)$ & $0 \mathrm{c}(0)$ & $40 \mathrm{bc}(8)$ & 90 a (18) & $100 \mathrm{a}(20)$ & $60(12)$ \\
\hline
\end{tabular}

${ }^{y}$ Numbers in parentheses represent number of plants out of 20 in which WSMV-GFP was observed at point of inoculation (PI) and systemic (Sys), and those in which virus was detected by ELISA at 21 days.

${ }^{\mathrm{z}}$ Means with the same letter within columns are not significantly different (Tukey-Kramer $P<0.05$ ). 
losses. Resistant cultivars bearing the $W s m l$ gene will have a gradual increase in virus movement within the plant and will only express symptoms when temperatures are higher than $25^{\circ} \mathrm{C}$ for a prolonged duration. This suggests that they are likely to suffer less WSMV damage and losses even under warm temperatures during fall and early spring. This disparity of impact between Mace and Tomahawk and the effects of varying temperatures was demonstrated by McMechan and Hein (2016) in a field study.

Other studies that have evaluated the effect of temperature on WSMV severity in wheat cultivars used a minimum temperature of $18^{\circ} \mathrm{C}$. In almost all cases, they report typical WSMV symptoms in the susceptible check within 14 days and no symptoms in resistant cultivars or germplasm carrying either the Wsml or the Wsm 2 gene (Seifers et al. 1995, 2006, 2007, 2013; Tatineni et al. 2010). However, a study by Price et al. (2014) shows that, when exposed to high temperatures $\left(28^{\circ} \mathrm{C}\right)$ for 4 weeks after inoculation with WSMV, Mace and RonL wheat bearing the Wsml and Wsm 2 genes, respectively, expressed severe WSMV symptoms and high virus titer. These plants failed to recover and even failed to produce heads after exposure to winter conditions with temperatures below the resistance threshold. This suggests that Mace can remain symptom-free, with little impact on yield under field conditions with cooler temperatures below $25^{\circ} \mathrm{C}$, but it will suffer severe symptoms and yield loss under prolonged temperatures above $25^{\circ} \mathrm{C}$.

The effect of temperature on plant resistance to viruses has been reported in other pathosystems. In contrast to WSMV in this study, low temperatures $\left(15\right.$ to $\left.25^{\circ} \mathrm{C}\right)$ increased virus replication, titer, and symptom severity of Soil-borne wheat mosaic virus, Tomato ringspot virus, Cymbidium ringspot virus, Citrus psorosis virus, and Cassava mosaic geminiviruses compared with temperature ranges of 26 to $32^{\circ} \mathrm{C}$ (Chellappan et al. 2005; Ghoshal and Sanfaçon 2014; Jovel et al. 2007; Myers et al. 1993; Ohsato et al. 2003; Siddiqui et al. 2008; Szittya et al. 2003; Velázquez et al. 2010). Temperature-sensitive resistance has been observed for TMV and Tomato spotted wilt virus (TSWV). TMV is able to overcome the $N$ gene resistance at temperatures above $28^{\circ} \mathrm{C}$ in tobacco (Király et al. 2008). However, TSWV is able to overcome $T s w$ gene-mediated resistance in pepper plants only at higher temperatures $\left(32^{\circ} \mathrm{C}\right)$ whereas plants remain asymptomatic at lower temperatures $\left(22^{\circ} \mathrm{C}\right.$ ) (Moury et al. 1998; Prasch and Sonnewald 2013). This is similar to the findings in our study, in which WSMV was able to overcome the Wsml temperature-sensitive resistance gene in Mace at temperatures above $25^{\circ} \mathrm{C}$.

The failure of ELISA to detect WSMV-GFP in some plants that expressed systemic WSMV-GFP infection, especially in Mace, could be due to testing tissue that did not include infection foci or possessed too low virus titer in these leaves. In some plants, virus was expressed in older leaves but not in the top two leaves that were harvested for testing. The lack of systemic infection by WSMV-GFP in Tomahawk at $10^{\circ} \mathrm{C}$ and Mace at 10 and $15^{\circ} \mathrm{C}$ by $21 \mathrm{dpi}$, compared with later expression of systemic infection at $27^{\circ} \mathrm{C}$ in regrowth plants, indicates that a small number of undetectable amounts of virus particles might have translocated to the crown, enabling the virus to multiply rapidly when plants were moved to optimal temperatures. A recent study failed to detect red fluorescent protein-labeled WSMV and virus titer in the leaf sheaths of inoculated leaves or crowns of the resistant Mace plants held at $18^{\circ} \mathrm{C}$ for 21 days (Tatineni et al. 2016). These findings indicate that there is potential for wheat plants to test negative for WSMV in ELISA during cool temperatures or in resistant cultivars, although these plants actually could possess scattered infection foci and would later develop symptoms under warm conditions that favor virus replication. Therefore, it is appropriate for studies using ELISA for field diagnosis to test samples once plants are exposed to suitable temperatures for virus replication.

TMV has been reported to move passively with photoassimilates without replication and spread under low temperatures; however, when plants are moved to higher temperatures, lesions appear in a shorter duration than normally required from time of inoculation to symptom expression, suggesting systemic infection but no replication or detection (Susi 1999). Casper and Holt (1996) failed to observe TMV tagged with GFP in xylem and phloem tissue despite the presence of infection foci in uninoculated leaves; they concluded that TMV moved via a vascular-mediated form of systemic transport without subgenomic expression or expression of GFP. These findings are similar to what we observed in our study. We failed to detect systemic GFP in plants that were held at low temperatures but, when they were transferred to a higher temperature $\left(27^{\circ} \mathrm{C}\right)$, these plants developed systemic GFP and even WSMV symptoms faster than they normally would after inoculation.

Prevailing climatic conditions, especially temperature, influence the impact of WSMV in both susceptible and resistant wheat cultivars. This study demonstrates a rapid increase in virus activity with increasing temperatures beginning about $15^{\circ} \mathrm{C}$ for a WSMV-susceptible variety (Tomahawk); however, this response to temperature is delayed considerably until temperatures increase to about $25^{\circ} \mathrm{C}$ in a WSMVresistant (Wsml) cultivar (Mace). In addition, in planta movement of WSMV at lower temperatures appears to be an important component of infection dynamics in winter wheat but this dynamic is significantly altered in plants with the Wsml resistance gene. Therefore, plants infected during the fall under cool temperatures that lose inoculated leaves during the winter may maintain the virus because of rapid translocation of WSMV to the crown. In susceptible plants, this will result in symptom development when warm conditions occur during the spring.

\section{Acknowledgments}

This project was supported by funds provided through the United States Department of Agriculture National Institute of Food and Agriculture grant number 201368004-20358. We thank W. W. Stroup and C. Stock for their assistance with statistical analysis; and J. Horrell, M. Bartels, E. Knoell, and J. McMechan for their invaluable assistance with the experiments.

\section{Literature Cited}

Appel, J. A., De Wolf, E., Bockus, W. W., and Bowden, R. L. 2013. Preliminary 2013. Kansas wheat disease loss estimates. Kansas Cooperative Plant Disease Survey Report.

Baulcombe, D. C., Chapman, S., and Cruz, S. S. 1995. Jellyfish fluorescent protein as a reporter for virus infections. Plant J. 7:1045-1053.

Browder, L. E. 1985. Parasite:host:environment specificity in the cereal rusts. Annu. Rev. Phytopathol. 23:201-222.

Brunt, A. A., Crabtree, K., Dallwitz, M., Gibbs, A., and Watson, L. 1996. Viruses of Plants. CAB International, Wallingford, UK.

Burrows, M., Franc, G., Rush, C., Blunt, T., Ito, D., Kinzer, K., Olson, J., O’Mara, J., Price, J., Tande, C., Ziems, A., and Stack, J. 2008. Occurrence of viruses in wheat in the Great Plains region. Online publication. Plant Health Prog. doi: 10.1094/PHP-2009-0706-01-RS

Byamukama, E., Seifers, D. L., Hein, G. L., De Wolf, E., Tisserat, N. A., Langham, M. A. C., Osborne, L. E., Timmerman, A., and Wegulo, S. N. 2013. Occurrence and distribution of Triticum mosaic virus in the central Great Plains. Plant Dis. 97:21-29.

Casper, S. J., and Holt, C. A. 1996. Expression of the green fluorescent proteinencoding gene from a Tobacco mosaic virus-based vector. Gene 173:69-73.

Chellappan, P., Vanitharan, R., Ogbe, F., and Fauquet, C. M. 2005. Effect of temperature on Geminivirus-induced RNA silencing in plants. Plant Physiol. 138:1828-1841

Colhoun, J. 1973. Effects of environmental factors on plant disease. Annu. Rev. Phytopathol. 11:343-364.

Cruz, S. S., Chapman, S., Roberts, A. G., Roberts, I. M., Prior, D. A., and Oparka, K. J. 1996. Assembly and movement of a plant virus carrying green fluorescent overcoat. Proc. Natl. Acad. Sci. USA 93:6286-6290.

Divis, L. A., Graybosch, R. A., Peterson, C. J., Baenziger, P. S., Hein, G. L., Beecher, B. B., and Martin, T. J. 2006. Agronomic and quality effects in winter wheat of a gene conditioning resistance to Wheat streak mosaic virus. Euphytica 152:41-49.

Dwyer, G. I., Gibbs, M. J., Gibbs, A. J., and Jones, R. A. C. 2007. Wheat streak mosaic virus in Australia: Relationship to isolates from the Pacific Northwest of the USA and its dispersion via seed transmission. Plant Dis. 91:164-170.

Ellis, M. H., Rebetzke, G. J., and Chu, P. 2003. First report of Wheat streak mosaic virus in Australia. Plant Pathol. 52:808.

Fahim, M., Mechanicos, A., Ayala-Navarrete, L., Haber, S., and Larkin, P. J. 2012. Resistance to Wheat streak mosaic virus-A survey of resources and development of molecular markers. Plant Pathol. 61:425-440.

Folimonova, S. Y., Folimonov, A. S., Tatineni, S., and Dawson, W. O. 2008 Citrus tristeza virus: Survival at the edge of the movement continuum. J. Virol. 82:6546-6556.

Friebe, B., Mukai, Y., Dhaliwal, H. S., Martin, T. J., and Gill, B. S. 1991. Identification of alien chromatin specifying resistance to wheat streak mosaic and greenbug in wheat germplasm by C-banding and in situ hybridization. Theor. Appl. Genet. 81:381-389. 
Garrett, K. A., Dendy, S. P., Frank, E. E., Rouse, M. N., and Travers, S. E. 2006. Climate change effects on plant disease: Genomes to ecosystems. Annu. Rev. Phytopathol. 44:489-509.

Ghoshal, B., and Sanfaçon, H. 2014. Temperature-dependent symptom recovery in Nicotiana benthamiana plants infected with Tomato ringspot virus is associated with reduced translation of viral RNA2 and requires ARGONAUTE 1. Virology 456-457:188-197.

Graybosch, R. A., Peterson, C. J., Baenziger, P. S., Baltensperger, D. D., Nelson, L. A., Jin, Y., Kolmer, J. A., Seabourn, B. W., French, R. C., and Hein, G. L. 2009. Registration of Mace hard red winter wheat. J. Plant Regist. 3:51-56.

Hunger, R. M., Sherwood, J. L., Evans, C. K., and Montana, J. R. 1992. Effects of planting date and inoculation date on severity of wheat streak mosaic in hard red winter wheat cultivars. Plant Dis. 76:1056-1060.

Jovel, J., Walker, M., and Sanfaçon, H. 2007. Recovery of Nicotiana benthamiana plants from a necrotic response induced by a nepovirus is associated with RNA silencing but not with reduced virus titer. J. Virol. 81:12285-12297.

Király, L., Hafez, Y. M., Fodor, J., and Király, Z. 2008. Suppression of Tobacco mosaic virus-induced hypersensitive-type necrotization in tobacco at high temperature is associated with down regulation of NADPH oxidase and superoxide and stimulation of dehydroascorbate reductase. J. Gen. Virol. 89:799-808.

Lu, H. J., Kottke, R., Devkota, R., St. Amand, P., Bernardo, A., Bai, G., Byrne, P., Martin, T. J., Haley, S. D., and Rudd, J. 2012. Consensus map- ping and identification of markers for marker assisted selection of Wsm2 in wheat. Crop Sci. 52:720-728.

Lu, H. J., Price, J., Devkota, R., Rush, C., and Rudd, J. 2011. A dominant gene for resistance to Wheat streak mosaic virus in winter wheat line CO960293-2. Crop Sci. 51:5-12.

McMechan, A. J., and Hein, G. L. 2016. Planning date and variety selection for management of viruses transmitted by the wheat curl mite (Acari: Eriophyidae). J. Econ. Entomol. 109:70-77.

Moury, B., Selassie, K. G., Marchoux, G., Daubèze, A., and Palloix, A. 1998. High temperature effects on hypersensitive resistance to Tomato spotted wilt tospovirus (TSWV) in pepper (Capsicum chinense Jacq.). Eur. J. Plant Pathol. 104:489-498.

Muller, P. Y., Janovjak, H., Miserez, A. R., and Dobbie, Z. 2002. Processing of gene expression data generated by quantitative real-time RT-PCR. Biotechniques 32:1372-1377.

Myers, L. D., Sherwood, J. L., Siegerist, W. C., and Hunger, R. M. 1993. Temperature-influenced virus movement in expression of resistance to Soilborne wheat mosaic virus in hard red winter wheat (Triticum aestivum). Phytopathology 83:548-551.

Ohsato, S., Miyanishi, M., and Shirako, Y. 2003. The optimal temperature for RNA replication in cells infected by Soil-borne wheat mosaic virus is $17^{\circ} \mathrm{C}$. J. Gen. Virol. 84:995-1000.

Oparka, K. J., Boevink, P., and Cruz, S. S. 1996. Studying the movement of plant viruses using green fluorescent protein. Trends Plant Sci. 1:412-418.

Pfaffl, M. W., Horgan, G. W., and Dempfle, L. 2002. Relative expression software tool (REST) for group-wise comparison and statistical analysis of relative expression results in real-time PCR. Nucleic Acids Res. 30:e36.

Prasch, C. M., and Sonnewald, U. 2013. Simultaneous application of heat, drought, and virus to Arabidopsis plants reveals significant shifts in signaling networks. Plant Physiol. 162:1849-1866.

Price, J. A., Simmons, A. R., Rashed, A., Workneh, F., and Rush, C. M. 2014. Winter wheat cultivars with temperature-sensitive resistance to Wheat streak mosaic virus do not recover from early-season infections. Plant Dis. 98: 525-531.

Roberts, A. G., Cruz, S. S., Roberts, I. M., Prior, D. A. M., Turgeon, R., and Oparka, K. J. 1997. Phloem unloading in sink leaves of Nicotiana benthamiana: Comparison of a fluorescent solute with a fluorescent virus. Plant Cell 9: 1381-1396.

Sánchez-Sánchez, H., Henry, M., Cardenas-Soriano, E., and Alviso-Villasana, H. F. 2001. Identification of Wheat streak mosaic virus and its vector Aceria tosichella in Mexico. Plant Dis. 85:13-17.

Seifers, D. L., Haber, S., Martin, T. J., and Zhang, G. 2013. New sources of temperature-sensitive resistance to Wheat streak mosaic virus in wheat. Plant Dis. 97:1051-1056.
Seifers, D. L., Harvey, T. L., Martin, T. J., and Jensen, S. G. 1997. Identification of the wheat curl mite as the vector of the High Plains virus of corn and wheat Plant Dis. 81:1161-1166.

Seifers, D. L., Martin, T. J., Harvey, T. L., Fellers, J. P., and Michaud, J. P. 2009 Identification of wheat curl mite as the vector of Triticum mosaic virus. Plant Dis. 93:25-29.

Seifers, D. L., Martin, T. J., Harvey, T. L., and Gill, B. S. 1995. Temperature sensitivity and efficacy of Wheat streak mosaic virus resistance derived from Agropyron intermedium. Plant Dis. 79:1104-1106.

Seifers, D. L., Martin, T. J., Harvey, T. L., and Haber, S. 2007. Temperaturesensitive Wheat streak mosaic virus resistance identified in KS03HW12 wheat. Plant Dis. 91:1029-1033.

Seifers, D. L., Martin, T. J., Harvey, T. L., Haber, S., and Haley, S. D. 2006 Temperature sensitivity and efficacy of Wheat streak mosaic virus resistance derived from CO960293 wheat. Plant Dis. 90:623-628.

Siddiqui, S. A., Sarmiento, C., Kiisma, M., Koivumäki, S., Lemmetty, A., Truve, E., and Lento, K. 2008. Effects of viral silencing suppressors on Tobacco ringspot virus infection in two Nicotiana species. J. Gen. Virol. 89:1502-1508.

Slykhuis, J. T. 1955. Aceria tulipae Keifer (Acarina: Eriophyidae) in relation to the spread of wheat streak mosaic. Phytopathology 45:116-128.

Staples, R., and Allington, W. B. 1956. Streak mosaic of wheat in Nebraska and its control. Univ. Neb. Coll. Agric. Exp. Stn. Res. Bull. 178.

Stenger, D. C., Hall, J. S., Choi, I. R., and French, R. 1998. Phylogenetic relationships within the family Potyviridae: Wheat streak mosaic virus and Brome streak mosaic virus are not members of the genus Rymovirus. Phytopathology 88:782-787.

Susi, P. 1999. Replication in the phloem is not necessary for efficient vascular transport of tobacco mosaic tobamovirus. FEBS Lett. 447:121-123.

Szittya, G., Silhavy, D., Molnár, A., Havelda, Z., Lovas, A., Lakatos, L., Bánfalvi, Z., and Burgyán, J. 2003. Low temperature inhibits RNA silencing-mediated defence by the control of siRNA generation. EMBO J. 22:633-640.

Tatineni, S., Graybosch, R. A., Hein, G. L., Wegulo, S. N., and French, R. 2010 Wheat cultivar-specific disease synergism and alteration of virus accumulation during co-infection with Wheat streak mosaic virus and Triticum mosaic virus. Phytopathology 100:230-238.

Tatineni, S., McMechan, A. J., Hein, G. L., and French, R. 2011. Efficient and stable expression of GFP through Wheat streak mosaic virus-based vectors in cereal hosts using a range of cleavage sites: Formation of dense fluorescent aggregates for sensitive virus tracking. Virology 410:268-281.

Tatineni, S., McMechan, A. J., Wosula, E. N., Wegulo, S. N., Graybosch, R. A., French, R., and Hein, G. L. 2014a. An eriophyid mite-transmitted plant virus contains eight genomic RNA segments with unusual heterogeneity in the nucleocapsid protein. J. Virol. 88:11834-1845.

Tatineni, S., Riethoven, J.-J. M., Graybosch, R. A., French, R., and Mitra, A. 2014b. Dynamics of small RNA profiles of virus and host origin in whea cultivars synergistically infected by Wheat streak mosaic virus and Triticum mosaic virus: Virus infection caused a drastic shift in the endogenous small RNA Profile. PLoS One 9:e111577.

Tatineni, S., Wosula, E. N., Bartels, M., Hein, G. L., and Graybosch, R. A. 2016. Temperature-dependent Wsm1 and Wsm2 gene-specific blockage of viral longdistance transport provides resistance to Wheat streak mosaic virus and Triticum mosaic virus in wheat. Mol. Plant-Microbe Interact. 29:724-738.

Tatineni, S., Ziems, A., Wegulo, S. N., and French, R. 2009. Triticum mosaic virus: A distinct member of the family Potyviridae with an unusually long leader sequence. Phytopathology 99:943-950.

Velázquez, K., Renovella, A., Comellas, M., Serra, P., García, M. L., Pina, J. A. Navarro, L., Moreno, P., and Guerri, J. 2010. Effect of temperature on RNA silencing of a negative- stranded RNA plant virus: Citrus psorosis virus. Plant Pathol. 59:982-990.

Wang, Y., Bao, Z., Zhu, Y., and Hua, J. 2009. Analysis of temperature modulation of plant defense against biotrophic microbes. Mol. Plant-Microbe Interact. 22:498-506

Wegulo, S. N., Hein, G. L., Klein, R. N., and French. R. C. 2008. Managing Whea Streak Mosaic. University of Nebraska-Lincoln Extension EC1871.

Wosula, E. N., McMechan, A. J., Oliveira-Hofman, C., Wegulo, S. N., and Hein, G. L. 2016. Differential transmission of two isolates of Wheat streak mosaic virus by five wheat curl mite populations. Plant Dis. 100:154-158. 